\title{
Associations between on-farm animal welfare indicators and productivity and profitability on Canadian dairies: I. On freestall farms
}

\author{
M. Villettaz Robichaud, ${ }^{1 *}$ J. Rushen, ${ }^{2}$ A. M. de Passillé, ${ }^{2}$ E. Vasseur, ${ }^{3}$ K. Orsel, ${ }^{4}$ and D. Pellerin ${ }^{1}$ \\ ${ }^{1}$ Department of Animal Science, University Laval, Québec, Québec, Canada, G1V 0A6 \\ ${ }^{2} \mathrm{UBC}$ Dairy Education and Research Centre, University of British Columbia, Agassiz, British Columbia, Canada, V0M 1A2 \\ ${ }^{3}$ Department of Animal Science, McGill University, Sainte-Anne-de-Bellevue, Québec, Canada, H9X 3V9 \\ ${ }^{4}$ Department of Production Animal Health, University of Calgary, Calgary, Alberta, Canada, T2N 4N1
}

\begin{abstract}
Motivating dairy producers to financially invest in the improvement of their animals' comfort and welfare can pose some challenges, especially when financial returns are uncertain. Economic advantages for dairy producers associated with increased animal welfare are likely to come from either a premium paid for the milk or increased productivity. The aim of the current study was to evaluate the associations between measures of herd productivity and farm profitability and animal-, management-, and resource-based indicators of cow welfare and comfort. The cow welfare measures were collected during a cow comfort assessment conducted on 130 Canadian freestall dairy farms, including 20 using an automatic milking system. Herd productivity and farm profitability measures were retrieved or calculated from data collected by the regional dairy herd improvement programs, and included milk production and quality, longevity, and economic margins over replacement costs. Univariable and multivariable linear regression models were used to assess the associations between welfare indicators and productivity and profitability measures. Increased yearly corrected milk production was associated with reduced prevalence of cows with knee lesions $[\beta=7.40 ; 95 \%$ confidence interval (CI): $2.6,12.2]$, dirty flanks $(\beta=26.9 ; 95 \%$ CI: 7.4, 46.5), and lameness ( $\beta=11.7 ; 95 \%$ CI: 3.3, 20.1). The farms' economic margin per cow, calculated over replacement costs, was associated with the within farm average lying time standard deviation $(\beta=-7.2 ; 95 \%$ CI: $-12.7,-1.7)$, percent of stalls with dry bedding ( $\beta$ $=6.4 ; 95 \%$ CI: $1.4,11.4$ ), and prevalence of cows with knee lesions ( $\beta=-5.1 ; 95 \%$ CI: $-8.9,-1.3)$. Some of the relationships found were complex, including several interactions between the animal-, management-, and
\end{abstract}

Received March 25, 2018.

Accepted January 28, 2019.

*Corresponding author: marianne.villettaz@gmail.com resource-based measures. Overall, the results suggest that improved cow comfort and welfare on freestall farms is associated with increased herd productivity and profitability, when the latest is calculated by the margins over the replacement costs.

Key words: productivity, profitability, welfare indicator, well-being

\section{INTRODUCTION}

Ensuring good animal welfare for food-production animals is a key concern of producers, the industry, and consumers (McInerney, 1998; Ventura et al., 2015; de Graaf et al., 2016). In recent decades, pressure has increased on dairy producers to improve their animals' comfort and welfare to satisfy new animal welfare standards and consumers' and food retailers' demands. Numerous on-farm animal welfare assessments are now offered to dairy producers, either on a voluntary basis or as part of mandatory programs (von Keyserlingk et al., 2012; National Milk Producers Federation, 2016; Villettaz Robichaud et al., 2018). The great majority of these on-farm assessments are followed by written reports and recommendations aiming to guide the producers toward improved animal welfare (Webster, 2012; Vasseur et al., 2015). To comply with these recommendations and animal welfare standards, producers will usually need to make some management changes or financial investments.

The majority of dairy farmers are favorable to the idea of ensuring good comfort and welfare of their animals (Kielland et al., 2010; Kauppinen et al., 2013). Previous surveys have shown that animal welfare is a priority for dairy farmers and the dairy industry in North America and Europe (Webster, 2012; Wolf et al., 2015; Hansson and Lagerkvist, 2016). However, making the changes required for the improvement of their animals' welfare seems to be difficult for some producers. Recent research looking at the adoption of changes after a cow comfort assessment found that over a quarter of the producers did not make changes 
following the recommendations provided at the end of the on-farm assessment. The greatest barriers to the adoption of new cow comfort practices were the lack of funds and time (Higginson Cutler et al., 2017; Nash et al., 2018). It is understandable that the lack of funds and the general costs of some modifications can be major external barriers; depending on the type of problem detected, the suggested solutions and associated costs may vary greatly, from a slight management change to a complete barn remodel (Christensen et al., 2012; Webster, 2012).

Economic advantages may play an important role in motivating some dairy producers to either change their practices or make the appropriate investments to improve their animals' welfare. Financial incentives are likely to arise from 2 sources: premiums paid for the farm's production when higher levels of animal welfare are achieved or a general improvement of the farm's productivity (i.e., direct performance of dairy cattle such as milk yield) and profitability (i.e., financial profits yield on milk production) as a direct result of improved animal welfare (Bennett et al., 2012; Christensen et al., 2012; Wolf et al., 2015). de Graaf et al. (2016) found that half of Belgian consumers expressed the intention to purchase animal-friendly milk if available but the market for specialty milk is likely to be limited as not all customers are inclined to pay a higher price for their milk (Wolf et al., 2016). Therefore, establishing the existence of associations between increased on-farm animal welfare and improved farm productivity may have a greater effect on producers' motivation to improve the current situation, especially under the Canadian dairy milk fat quota system.

Only a limited number of studies have investigated the relations between freestall farms' profitability and on-farm cow comfort. We previously investigated the associations between farms' results, meeting or not specific criteria, during an animal welfare assessment and their productivity (Villettaz Robichaud et al., 2018). The results indicated that meeting a greater number of criteria was partially associated with better productivity and profitability but also highlighted the limitations of using cut-off thresholds to evaluate the success of a farm in term of animal welfare in its associations with farm productivity, as some of the animal welfare thresholds were met by either very few or almost all farms, which limited their use for statistical analysis. To improve the financial guidance provided to producers in their animal welfare-oriented decisions, it is necessary to investigate the associations between the prevalence of on-farm animal welfare indicators, measured on a continuous scale, and farm productivity and profitability. The objective of the present study was to evaluate the associations between animal-, management-, and resource-based welfare indicators and measures of herd productivity and farm profitability in Canadian freestall dairy farms.

\section{MATERIALS AND METHODS}

The institutional animal care committees and research ethics boards of the University of Calgary (Calgary, Alberta, Canada), University of Guelph (Guelph, Ontario, Canada), and Université Laval (Québec, Québec, Canada) approved all procedures.

\section{Herd and Animal Selection}

This study is part of a large Canadian study investigating on-farm cow comfort, for which a total of 130 freestall dairy farms, 110 with milking parlors and 20 with automatic milking systems (AMS), were visited (Vasseur et al., 2015). These farms were situated in the 3 highest milk producing provinces of Canada: Alberta $(\mathrm{n}=51)$, Ontario $(\mathrm{n}=50)$, and Québec $(\mathrm{n}=29)$. The general production and welfare characteristics of the farms are shown in Table 1. Participation in the study was voluntary following initial contact with the producers through mailed letters (Alberta and Ontario) or phone calls from their Dairy Herd Improvement Agency (DHIA) advisor (Québec). To participate in the study, the herds needed to have a minimum of 40 Holstein dairy cows in lactation and be enrolled in their regional DHIA (CanWest DHI in Alberta and Ontario; Valacta Inc. in Québec). In addition, farms had to not provide outdoor access to their lactating animals, have used their current housing system for at least $1 \mathrm{yr}$, have an average milk production $\geq 7,000 \mathrm{~kg}$ per cow per year, and participate in The Alberta Hoof Health Project for the farms enrolled in Alberta (Solano et al., 2015; Vasseur et al., 2015). Another farm selection criterion was based on the cows' longevity, in terms of proportion of cows in third lactation or higher and replacement rate, to capture herds with low-, medium-, and highlongevity level at the provincial level and was applied through a stratified randomization process during the formulation of the initial list of producers to contact (Vasseur et al., 2015). On each farm, 40 lactating cows were purposively selected for data collection based on parity and DIM. Ideally, cows were selected between 10 and 120 DIM, with the proportion of primiparous cows in the sample reflecting the overall proportion in the herd, when possible. If a farm did not have 40 milking cows between 10 and 120 DIM, the selection was extended beyond 120 DIM until 40 cows were selected. The mean DIM of all the cows evaluated was $108 \pm$ 82 (SD). The overall average difference between the proportion of primiparous cows sampled (38\%) and the 
Table 1. Production characteristics and animal welfare indicators of the 110 milking parlor and 20 automatic milking system Canadian dairy farms enrolled and univariable regression models investigating the difference between freestall with milking parlor and AMS farms

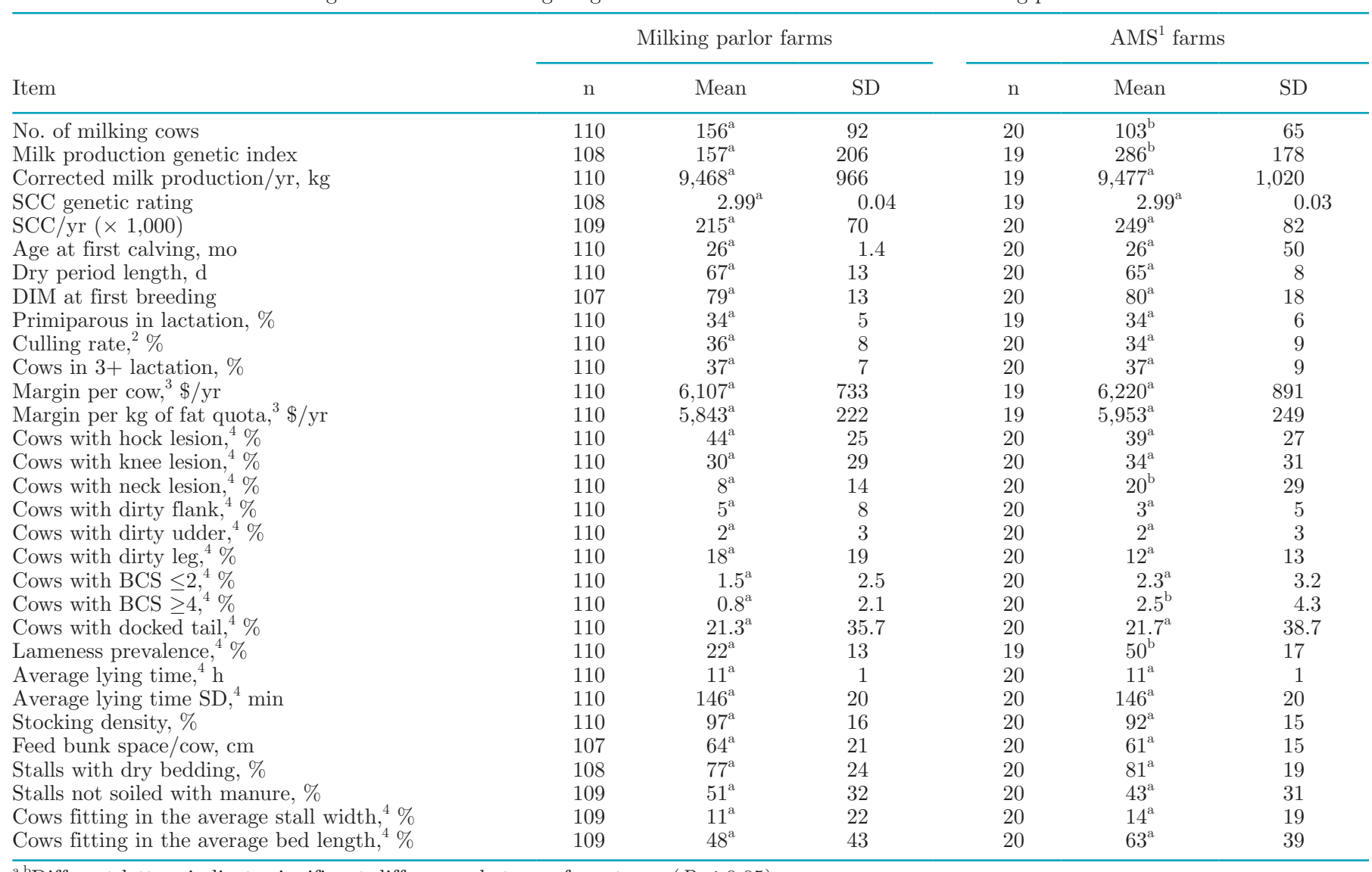

${ }^{\mathrm{a}, \mathrm{b}}$ Different letters indicate significant differences between farm types $(P \leq 0.05)$.

${ }^{1} \mathrm{AMS}=$ automatic milking system.

${ }^{2}$ Culling for any other reasons than sold for milk production.

${ }^{3}$ Calculated over replacement costs.

${ }^{4}$ Estimated using the 40 cows per herd.

actual proportion of primiparous $(34 \%)$ in the respective herds was $4 \%$.

\section{Data Collection and Handling}

Across the provinces, 15 observers were trained to collect all the animal-, management-, and resource-based measures (Vasseur et al., 2013). The farm visits were conducted between January 2011 and April 2012 and each farm was visited by a pair of trained observers. Strict standard scoring training and protocols, which included both written descriptions and pictures, were used for lesions, dirtiness, BCS, stall, and lameness assessment to ensure high repeatability between all observers (Gibbons et al., 2012). Intra-observer repeatability and repeatability compared with the training instructor were tested twice for each observer over the data collection period (Gibbons et al., 2012; Vasseur et al., 2013). Selected cows' hocks and knees were scored using 4-level scoring systems (0 to 3 ), and the neck area was scored using a 3-level scoring system (0 to 2), previously reported in detail by Gibbons et al. (2012) and Zaffino Heyerhoff et al. (2014). A cow was considered as having a lesion if 1 leg for the respective area had a lesion score of 2 or more. Similarly, cows were considered as having a neck lesion when they had a score of 2 for this area. Leg, flank, and udder dirtiness were scored using a 4-level scoring systems (available at https:// www.dairyresearch.ca/animal-comfort-tool.php). For each selected cow, only the right flank and lower leg were scored for dirtiness. Cows were considered as dirty if they received a score of 2 or more. The selected cows' BCS were scored using a simplified flowchart with BCS ranging from $<2$ to 5 previously reported in detail by Vasseur et al. (2013). The farms' lameness prevalence was estimated based on the locomotion score assessed for the 40 selected cows. Individual video recordings were taken for each cow and used a posteriori to score 
the locomotion of each cow. Cows were observed walking for at least 4 strides, and the presence or absence of a limp was recorded (Charlton et al., 2014; Solano et al., 2015). Lying time was recorded using Hobo G Acceleration loggers (Hobo Pendant G Acceleration Data Logger, Onset Computer Corp., Pocasset, MA) fitted to one of the hind legs of each of the 40 selected cows using CoFlex bandage wrap (CoFlex, Andover Coated Products Inc., Salisbury, MA). The loggers, previously validated to record lying and standing position, were programmed to record the cows' position at 1-min intervals for 4 consecutive 24 h (Ledgerwood et al., 2010; Charlton et al., 2014; Solano et al., 2016). Previous research showed that a sampling of $4 \mathrm{~d}$ of continuous lying data is sufficient to get a representative estimate of herd average lying time (Ito et al., 2009; Vasseur et al., 2012). The average lying time standard deviation (SD) per farm was calculated using the SD for the $4 \mathrm{~d}$ average lying time of the individual selected cows.

Resource- and management-based measures for each farm were collected either through a questionnaire administered by the trained observer during the farm visit, measured directly in the barn or through the regional DHIA data. The questionnaire administered on-farm contained a total of 68 questions covering a wide variety of subjects related to the farms' management for housing, feeding, health, lameness, and calving. Stocking density of housing pen was calculated using the number of cows in the pen divided by the number of usable stalls. Feed bunk space per cow was calculated using the length of the feeding space usable by the animals divided by the number of cows in the pen. The level of dryness of the bedding in the stall was scored on 6 stalls for each farm using a standard protocol available at https://www.dairyresearch.ca/animal -comfort-tool.php. The level of manure soiling of the stalls was evaluated using a 5-level scoring system and assessed on the same 6 stalls used to evaluate bedding dryness. The 5 levels varied from no soiling to entirely contaminated. The proportion of cows fitting the average stall width or bed length was calculated using the cow and stall dimensions collected during the in-barn assessment and the stall dimension recommendations for freestall housing (http://www.omafra.gov.on.ca/ english/livestock/dairy/facts/freestaldim.htm). The standard operating procedures followed to collect this information are available at https://www.dairyresearch .ca/animal-comfort-tool.php. A cow was classified as fitting the average stall width if the average stall width at the loops at the center was larger than her hookbone width multiplied by 2 . A cow was classified as fitting the average bed length if the average bed length was longer than 1.2 times her rump height (Anderson, 2016).
The productivity indicators for each farm were based on the data collected by the regional DHIA programs during the 12 mo previous to the farm visit. Farm productivity indicators included in this study were farm averages for yearly fat- and protein-corrected milk production $(\mathrm{kg})$, yearly SCC, culling rate (\%), and percentage of cows in third lactation or greater (\%). For this study, culling rate was calculated using the assumption that a cow was considered culled if she left the production herd for any reason other than being sold to another farm for milk production purposes. The overall profitability of farms was assessed through yearly economic margins per cow and per kilogram of dairy fat production quota, both calculated over replacement costs exclusively. The profitability margins were calculated for each farm using the 5-yr average prices (2010 to 2015$)$ for milk solids $(\$ 9.67 / \mathrm{kg}$ of fat; $\$ 8.89 / \mathrm{kg}$ of proteins; $\$ 1.75 / \mathrm{kg}$ of other solids) and cull cow meat $(\$ 795 / \mathrm{cow})$, and average costs for milk marketing $(\$ 0.14 / \mathrm{kg}$ of milk solids), milk transportation $(\$ 2.559 / \mathrm{hL})$, heifer raising (\$3,395/animal), and dead cow removal $(\$ 60 /$ cow $)$. The same prices for milk solids and other costs were used to calculate the margins for all farms across the country. These margins were calculated exclusively over the replacement costs and therefore did not include costs such as feed, bedding, or veterinary services, as these were not available.

\section{Statistical Analyses}

Stata 13 statistical software (StataCorp LP, College Station, TX) was used to analyze the data. Descriptive statistics were generated to describe the characteristics of the farms included in this study independently for farms with milking parlor and AMS. Correlation coefficients between animal-based measures were computed using Spearman correlations. Univariable linear regression statistics were conducted between farms' productivity and profitability outcomes and farms' characteristics, animal-, management-, and resourcebased measures for all 130 farms together.

Multivariable linear regression models were used to analyze the association between farm characteristics, animal-, management-, and resource-based measures and the following profitability indicators: average yearly fat- and protein-corrected milk production (kg; corrected at $4 \%$ of fat and $3.3 \%$ of true protein), average yearly SCC, culling rate (\%), percentage of cows in third lactation or higher (\%), yearly margin per cow over replacement costs, and yearly margin per kilogram of dairy fat production quota over replacement costs. The farms' characteristics and the animal-, management-, and resource-based measures tested as predictor variables for each statistical model are presented 
in Table 1 along with the outcomes evaluated. Farm milking system type (milking parlor or AMS), province where the farm was located, whether or not they fed TMR, and the frequency of scheduled hoof trimming were categorical predictors also tested in each model. For any covariate, the initial cut-off value of $P<0.2$ in the univariable analysis was used as a prerequisite to be included in a multivariable model. Backward manual selection was used to remove all nonsignificant terms in the models. Interactions between predictors included in the multivariable models were investigated and kept in the models if statistically significant. The significance level was set at $\alpha=0.05$ for a variable to be retained in the final models. Partial F-tests and Akaike and Bayesian information criteria were used to assess the effect of removing categorical variables from models. Regardless of their statistical significance, confounding variables were retained in the models. Confounding variables were identified based on a causal diagram and if their removal resulted in a change of $20 \%$ or greater on the other significant variable coefficients.

For each linear model, the assumption of linearity was assessed visually based on the distribution of the residuals against the continuous predictors included in the model. If nonlinear, the variable was either modeled as a quadratic relationship, if appropriate based on visual assessment of locally weighed regression curves (Lowess curves) or categorized. Collinearity between predictors was tested using the variance inflation factors. If 2 variables were found to be highly correlated (variance inflation factor $\geq 10$ ), only the variable with a higher level of interest to the study was used in the final model. The variables' level of interest was based on the causal diagram drawn before the statistical analysis where priority was given to animal welfare indicators over farm characteristics. Homoscedasticity and normality of the residuals were assessed visually using the distribution of the standardized residuals against the predicted values of the outcomes and the normal quantile plots, respectively. Outliers and influential observations were identified using visual assessment of standardized residuals, leverage, Cook's distance, and DFITS. If an observation was found to be an outlier or an influential observation but had no unusual characteristics, it was kept in the model.

\section{RESULTS}

\section{Characteristics of Farms Enrolled}

The characteristics of the farms enrolled in this study are presented in Table 1. A total of $94 \%$ of the farms fed TMR to their lactating cows. Hoof trimming was scheduled once per year on $16 \%$ of farms, twice per year on $40 \%$ of farms, and 3 times or greater per year on $44 \%$ of farms. The AMS farms had a significantly lower number of cows and average percentage of very wet stall and higher inbreeding coefficients, milk genetic index, estimated hock lesions, and lameness prevalence than farms with a conventional milking parlor (Table 1). The herd prevalence of the animal-based welfare indicators were estimated using the data collected on the 40 selected cows. No strong correlation $(\rho>0.75)$ were found between the animal-based measures analyzed, but a some positive correlation $(\rho>0.45)$ was found between the percentage of cows with dirty flanks and dirty udder (Table 2). These were also positively correlated with the percentage of cows with dirty legs, but with a smaller coefficient.

\section{Milk Production and Yearly SCC}

Lower average milk production was associated with a higher percentage of lame cows $(-12 \mathrm{~kg}$ per $\%)$ and cows with knee lesions $(-7.4 \mathrm{~kg}$ per \%), dirty flank $(-27 \mathrm{~kg}$ per \%), and fitting in the average bed length

Table 2. Spearman correlation coefficients between estimated prevalence of the animal-based welfare measures on 130 freestall dairy farms in Alberta, Ontario, and Québec, Canada

\begin{tabular}{|c|c|c|c|c|c|c|c|c|c|c|}
\hline Item & Hock & Knee & Neck & Flank & Udder & Leg & $\mathrm{BCS} \leq 2$ & BCS $\geq 4$ & Lameness & $\begin{array}{l}\text { Lying } \\
\text { time }\end{array}$ \\
\hline $\mathrm{n}$ & 130 & 130 & 130 & 130 & 130 & 130 & 130 & 130 & 129 & 130 \\
\hline Hock lesions & 1 & & & & & & & & & \\
\hline Neck lesions & 0.001 & 0.227 & 1 & & & & & & & \\
\hline Flank dirtiness & 0.052 & -0.050 & 0.064 & 1 & & & & & & \\
\hline Udder dirtiness & 0.091 & -0.124 & -0.040 & 0.539 & 1 & & & & & \\
\hline $\mathrm{BCS} \geq 4$ & -0.063 & 0.075 & 0.031 & -0.109 & -0.002 & -0.082 & 0.019 & 1 & & \\
\hline Lameness prevalence & 0.190 & 0.113 & -0.001 & -0.076 & 0.030 & -0.131 & 0.173 & 0.129 & 1 & \\
\hline Average lying time & -0.307 & 0.078 & 0.053 & 0.055 & 0.001 & -0.288 & 0.093 & 0.139 & 0.139 & 1 \\
\hline Average lying time SD & 0.362 & -0.022 & -0.035 & 0.225 & 0.136 & 0.147 & 0.186 & -0.113 & 0.334 & -0.145 \\
\hline
\end{tabular}


Table 3. Multivariable linear regression model investigating the associations between average corrected milk production $(\mathrm{kg})$ and farms' management practices and animal welfare indicators on 120 freestall farms in Alberta, Ontario, and Québec, Canada

\begin{tabular}{|c|c|c|c|}
\hline Model/predictor & $\beta$ & $95 \% \mathrm{CI}$ & $P$-value \\
\hline Milk production genetic index & 1.31 & $0.603,2.008$ & $<0.001$ \\
\hline DIM at first breeding & 10.92 & $0.281,21.559$ & 0.044 \\
\hline Stalls with dry bedding, $\%$ & 9.92 & $3.727,16.113$ & 0.002 \\
\hline Cows fitting in the average bed length, ${ }^{1} \%$ & -3.62 & $-6.956,-0.278$ & 0.034 \\
\hline \multicolumn{4}{|l|}{ Feed $\mathrm{TMR}^{2}$} \\
\hline No & Referent & - & - \\
\hline Yes & $1,079.71$ & $514.647,1,644.768$ & $<0.001$ \\
\hline Cows with knee lesion, ${ }^{1} \%$ & -7.40 & $-12.215,-2.590$ & 0.003 \\
\hline Cows with dirty flank, ${ }^{1} \%$ & -26.92 & $-46.487,-7.360$ & 0.007 \\
\hline Lameness prevalence, ${ }^{1} \%$ & -11.69 & $-20.117,-3.260$ & 0.007 \\
\hline
\end{tabular}

${ }^{1}$ Estimated using the 40 cows per herd.

${ }^{2}$ Feed TMR: $\mathrm{n}=112$; do not feed TMR: $\mathrm{n}=8$.

$(-3.6 \mathrm{~kg}$ per \%; Table 3). Higher average milk production was associated with higher proportion of stalls with dry bedding (10 kg per \%), feeding TMR, higher milk production genetic index, and higher DIM at first breeding (Table 3).

No animal-based welfare indicator was associated with the average SCC per year. However, the average SCC was 460 lower for each 1\% increase in the number of stalls that were not soiled with manure (Table 4). Average SCC was also significantly lower with higher milk production genetic index. Increasing average SCC genetic rating, number of cows, and age at first calving were all associated with increased average SCC per year (Table 4). The SCC per year was also significantly higher by over 50,000 in AMS farms compared with farms with conventional milking parlors.

\section{Culling Rate and Longevity}

Each 1\% increase in the estimated proportion of cows with BCS $\leq 2$ was associated with a $0.5 \%$ lower culling rate, whereas a higher proportion of cows with BCS $\geq 4$ was associated with a higher culling rate $(0.5 \%$ per $\%$; Table 5). Lameness prevalence and average DIM at first breeding interacted together in their association with culling rate, leading to increasing culling rates with increasing estimated lameness prevalence on farms where the average DIM at first breeding was less than 72 DIM and the opposite relation in farms where average DIM at first breeding was over 72 DIM (Figure 1). Greater frequency of scheduled hoof trimming sessions per year was also significantly associated with a higher culling rate (Table 5).

The percentage of cows in third lactation or greater in the herd was positively associated with the estimated proportion of cows fitting in the average bed length $(0.03 \%$ per $\%)$ and negatively associated with the average milk production genetic index (Table 6).

\section{Farm Profitability Margins}

Farm yearly margin per cow over replacement costs was significantly lower in farms with a higher proportion of cows with knee lesions ( $\$ 5$ per $\%$ ), a greater estimated SD in their cows' average daily lying time (\$431 per $\mathrm{h}$ ), and longer dry period (\$16 per d; Table 7). Margin per cow was higher with a greater percentage of stalls with dry bedding (\$6 per \%), average DIM at first breeding, and average milk production genetic index (Table 7). Farms located in the province of Al-

Table 4. Multivariable linear regression model investigating the associations between average SCC production $(\times 1,000)$ and farms' management practices and animal welfare indicators on 125 freestall farms in Alberta, Ontario, and Québec, Canada

\begin{tabular}{lccc}
\hline Model/predictor & $\beta$ & $95 \%$ CI & $P$-value \\
\hline Milk production genetic index & -0.07 & $-0.123,-0.009$ & 0.024 \\
SCC genetic rating & 567.43 & $241.868,892.990$ & 0.001 \\
Number of cows & 0.13 & $0.002,0.259$ & 0.046 \\
Age at first calving, d & 0.53 & $0.277,0.787$ & $<0.001$ \\
Stalls not soiled with manure, $\%$ & -0.46 & $-0.802,-0.113$ & 0.010 \\
Farm type & & & - \\
Milking parlor & Referent & $-19.086,82.941$ & 0.002 \\
Automatic milking system & 51.01 &
\end{tabular}

${ }^{1}$ Milking parlor: $\mathrm{n}=106$; automatic milking system: $\mathrm{n}=19$. 
Table 5. Multivariable linear regression model investigating the associations between culling rate (\%) and farms' management practices and animal welfare indicators on 126 freestall farms in Alberta, Ontario, and Québec, Canada

\begin{tabular}{|c|c|c|c|}
\hline Model/predictor & $\beta$ & $95 \% \mathrm{CI}$ & $P$-value \\
\hline DIM at first breeding & 0.08 & $-0.116,0.286$ & 0.404 \\
\hline Lameness prevalence, ${ }^{1} \%$ & 0.54 & $0.016,1.056$ & 0.044 \\
\hline Cows with $\mathrm{BCS} \leq 2,{ }^{1} \%$ & -0.54 & $-1.045,-0.037$ & 0.036 \\
\hline Cows with BCS $>4,{ }^{1} \%$ & 0.53 & $0.024,1.033$ & 0.040 \\
\hline \multicolumn{4}{|l|}{ Frequency of scheduled hoof trimming $/ \mathrm{yr}^{2}$} \\
\hline Once & Referent & - & - \\
\hline Twice & 3.89 & $0.080,7.706$ & 0.045 \\
\hline Routinely $(\geq 3)$ & 5.00 & $1.176,8.816$ & 0.011 \\
\hline Lameness prevalence $\times$ DIM at first breeding & -0.007 & $-0.014,-0.001$ & 0.028 \\
\hline
\end{tabular}

${ }^{1}$ Estimated using the 40 cows per herd.

${ }^{2}$ Once: $\mathrm{n}=21$; twice: $\mathrm{n}=51$; routinely: $\mathrm{n}=54$.

berta also had higher yearly margin per cow compared with farms located in Québec, but no differences were found in farms located in Ontario.

The yearly margin per kilogram of dairy fat production quota over replacement costs was significantly associated with an interaction between the percentage of cows with a neck lesion and the average milk production genetic index (Table 8). On farms with less than $28 \%$ of cows having a neck lesion, the increase in yearly margin per kilogram of dairy fat production quota with a higher average milk production genetic index was steeper with lower prevalence of neck lesions (Figure 2).

\section{DISCUSSION}

Our objective was to evaluate the associations between measures of farm productivity and profitability and on-farm prevalence of several animal-, management-, and resource-based welfare indicators. The on-farm prevalence of animal-based indicators was estimated using the data collected on the 40 cows selected for

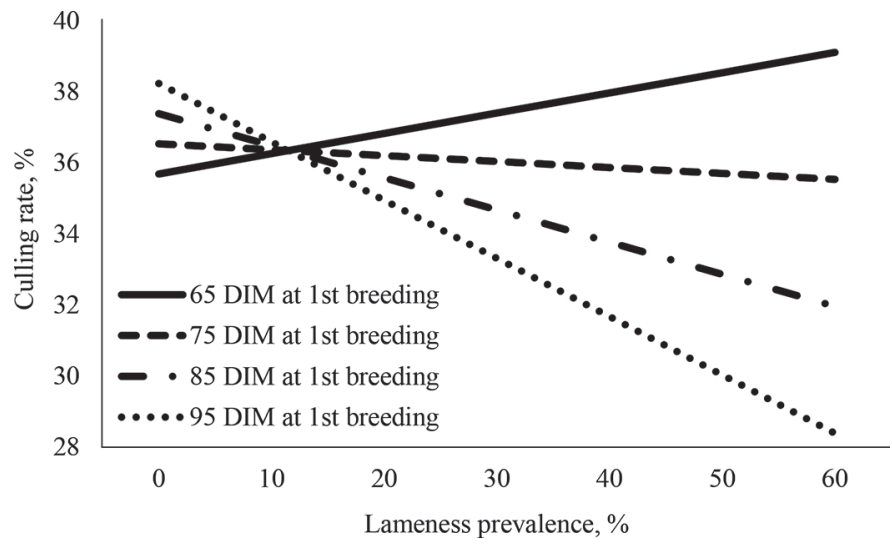

Figure 1. Effect of the interaction between the average DIM at first breeding and the estimated lameness percentage on the culling rate (\%) on 126 freestall farms in Alberta, Ontario, and Québec, Canada. each herd. We found that good cow welfare, based on the parameters assessed, was associated with improved production and longevity, which was reflected in greater economic margins at the farm level. No strong correlations between the estimated on-farm prevalence of the different welfare indicators were found. Unsurprisingly, the highest positive correlations were found between the flank, udder, and leg cleanliness measures, which are all generally linked with the bedding available and cleanliness in the lying stalls (Norring et al., 2008). The prevalence of dirty legs was also positively correlated with hock lesion prevalence, and average lying time was negatively correlated with both of these measures. This may be due to uncomfortable stalls, reducing the cows' lying time while increasing injuries and dirtiness (Zaffino Heyerhoff et al., 2014; Westin et al., 2016). Norring et al. (2008) found that straw bedding was associated with increased lying time, hock lesions, and leg dirtiness whereas other research found that stall base and bedding dryness also affected lying time, leg lesions, or cleanliness (Wechsler et al., 2000; Fregonesi et al., 2007; van Gastelen et al., 2011). The estimated SD of average lying time per day within farm was slightly correlated with the lameness prevalence, which was expected as many research have previously shown the associations between lying behavior and lameness, which were in some cases were modulated by the stall base (Ito et al., 2010; Blackie et al., 2011; Solano et al., 2016).

Farm selection process was not truly random due to the inclusion criteria but the final sample of farms was representative of the Canadian dairy industry based on average milk production, herd size and other farm characteristics (AAFC, 2016; PLQ, 2016). The type of milking system (AMS or conventional milking parlor), on its own, did not influence the measures of farm productivity and profitability. However, the DIM selection criterion applied during the animals' selection may have led to an overestimation of some animal-based welfare problems as cows in early lactation are at greater risks 
Table 6. Multivariable linear regression model investigating the associations between the proportion of cows in their third or greater lactation (\%) and farms' management practices and animal welfare indicators on 126 freestall farms in Alberta, Ontario, and Québec, Canada

\begin{tabular}{lccc}
\hline Model/predictor & $\beta$ & $95 \%$ CI & $P$-value \\
\hline Milk production genetic index & -0.007 & $-0.013,-0.001$ & 0.03 \\
Cows that fit the average bed length, ${ }^{1} \%$ & 0.03 & $0.002,0.060$ & 0.039 \\
\hline
\end{tabular}

${ }^{1}$ Estimated using the 40 cows per herd.

of lameness and health issues (Green et al., 2002). The results of this study may have limited applicability for farms with characteristics greatly different from those of the farms enrolled in this study. Additionally, it is important to note that the actual data collection on farm was done 6 or 7 yr ago. Since then, the awareness of dairy producers of the importance of animal welfare and comfort has greatly increased and some mandatory programs have been put in place (Villettaz Robichaud et al., 2018). However, because both the animal welfare measures and the production data used in this study were from the same period of time, we expect that associations would be identified if current animal welfare and production data were used.

Farms with lower estimated prevalence of knee lesions, dirty flanks, and lame cows had a greater average milk production. Cow cleanliness, leg lesions, and lameness prevalence have all previously been linked with stall design and management (Bernardi et al., 2009; Lombard et al., 2010; Solano et al., 2015). Because milk production is thought to be maximized when the cows are resting sufficiently, it is expected that greater comfort and welfare, provided through adequate housing and evaluated through the animal-based measures, are associated with increased milk production. However, interestingly, no association between the average lying

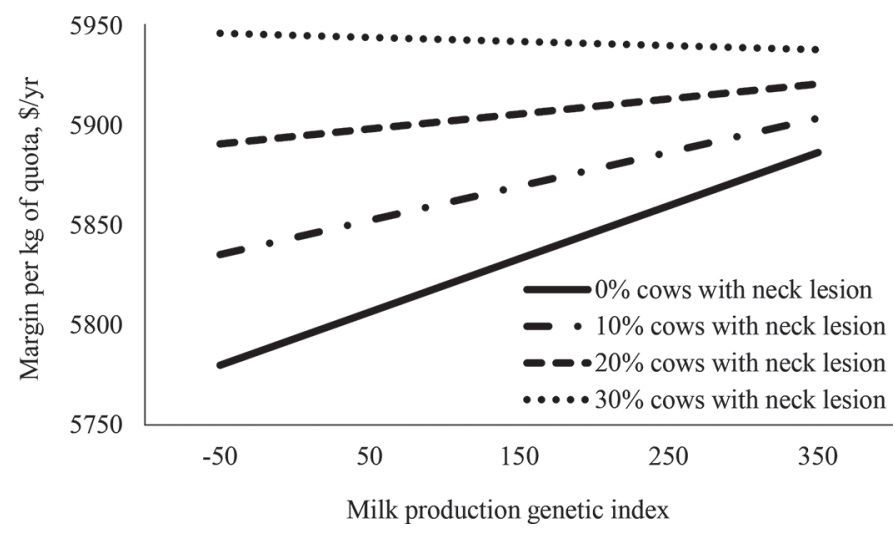

Figure 2. Effect of the interaction between the estimated percentage of cow with a neck lesion (\%) and average milk production genetic index on the economic margin per kilogram of dairy fat production quota over replacement costs (\$) on 126 freestall farms in Alberta, Ontario, and Québec, Canada. time and milk production was found, contrary to previously published information at the cow level (Grant, 2007). Previous studies have also shown associations between lying time and lameness and that the type of lying surface influenced this association (Ito et al., 2010; Solano et al., 2016; Westin et al., 2016). Therefore, our results may indicate that milk production is associated with primary effects of the lying surface, such as lameness and leg lesions, more than with their resulting effects on lying behavior. The prevalence of clean stalls was positively associated with milk quality with a reduction in SCC $(-460$ per \%). This was expected because previous research has shown the link between stall cleanliness, stall dimensions, and udder health (Bernardi et al., 2009; Dohmen et al., 2010). Previous research has also shown that cow cleanliness affects milk quality (Sant'anna and Paranhos da Costa, 2011). The 3 measures of cow cleanliness included in our study were not significantly associated with milk quality, but this is likely due to the very low prevalence of dirty animals on the farms visited.

Culling rate was mainly associated with cow BCS and lameness. More frequently scheduled hoof trimmings per year and a higher estimated lameness prevalence were both associated with a higher culling rate. However, the lameness prevalence interacted with the DIM at first breeding, leading to unexpected results; in farms where DIM at first breeding was later than $72 \mathrm{~d}$, higher lameness prevalence was associated with reduced culling rate. These results could indicate that farms working toward improvement of lameness issues may be using regular hoof trimming and culling as part of their hoof health strategy. The interaction between DIM at first breeding and estimated lameness prevalence may be revealing information on the culling strategy of the farms. In farms with low levels of lameness, the increased culling rate with increasing DIM at first breeding could be linked with a culling strategy based on reproduction problems. In farms with higher prevalence of lameness, the lower culling rate with additional DIM at first breeding could be linked with a culling strategy based on milk production levels.

Within all the predictors evaluated, the proportion of the milking herd composed of cows in their third or more lactation was only positively associated with the 
Table 7. Multivariable linear regression model investigating the associations between economic margin per cow over replacement costs $(\$)$ and farms' management practices and animal welfare indicators on 122 freestall farms in Alberta, Ontario, and Québec, Canada

\begin{tabular}{lccr}
\hline Model/predictor & $\beta$ & $95 \%$ CI & $P$-value \\
\hline Milk production genetic index & 1.16 & $0.607,1.723$ & $<0.001$ \\
DIM at first breeding & 14.94 & $6.440,23.440$ & 0.001 \\
Dry period length, d & -16.24 & $-25.635,-6.849$ & 0.001 \\
Average lying time SD, ${ }^{1}$ min & -7.18 & $-12.704,-1.661$ & 0.011 \\
Feed TMR ${ }^{2}$ & & & - \\
No & Referent & $-1.90 .654,1,165.158$ & 0.003 \\
Yes & 702.91 & $1.370,11.423$ & 0.013 \\
Stalls with dry bedding, \% & 6.40 & $-8.908,-1.319$ & 0.009 \\
Cows with knee lesion, $^{3} \%$ & -5.11 & & - \\
Province of location $^{3}$ & & $-86.526,514.659$ & 0.161 \\
Québec & Referent & $30.748,670.060$ & 0.032 \\
Ontario & 214.07 & & \\
Alberta & 350.40 & & \\
\hline
\end{tabular}

${ }^{1}$ Estimated using the 40 cows per herd.

${ }^{2}$ Feed TMR: $\mathrm{n}=114$; do not feed TMR: $\mathrm{n}=8$.

${ }^{3}$ Alberta: $\mathrm{n}=48$; Ontario: $\mathrm{n}=47$; Québec: $\mathrm{n}=27$.

percentage of cows fitting in the average bed length and negatively with the milk production genetic index. The negative association with genetic index was expected because younger animals tend to have higher milk genetic index, and therefore, farms with a greater proportion of older cows should have lower average index. The association with the proportion of animal fitting the bed length may be explained by the greater comfort of the animals provided through adequate housing size, which affects lying behavior, leg lesions, lameness, and milk production and consequently allows cows to be kept in the herd longer (Bernardi et al., 2009; Bouffard et al., 2017).

The profitability margins, calculated exclusively on replacement costs, were associated with different measures of cow welfare depending on whether the margins were calculated per cow or per kilogram of dairy fat production quota. Interestingly, a greater estimated SD in average daily lying times within a farm was associated with lower margin per cow. Previous studies have shown that cows' lying time on a farm may better be expressed in terms of the variation among individual cows within farms and this measure is associated with lameness prevalence and cow housing comfort (Ito et al., 2009, 2010; Deming et al., 2013). In contrast, the margin per kilogram of dairy fat production quota was mainly associated with the prevalence of neck lesions indicating that this margin may reflex the effects of cow welfare related to the feeding area and management more than resting area (Zaffino Heyerhoff et al., 2014). The interaction found with the milk genetic index shows that the effect of better genetic can be maximize when cows are provided with better feeding environment and management. Feed, bedding, and veterinary costs were not available for each farm visited and therefore could not be included in the calculation of the margins. The addition of these parameters could have influenced the farm profitability results.

\section{CONCLUSIONS}

The results of this study provide indications to dairy farmers using freestall housing, under the Canadian quota system, that greater cow comfort and welfare on-farm can benefit them financially through improved production and enhanced profitability, when calculated exclusively over the replacement costs. The results also emphasize that to maximize the financial benefits of good welfare, every aspect of housing needs to provide the highest level of comfort for the animals. Dairy

Table 8. Multivariable linear regression model investigating the associations between economic margin per kilogram of dairy fat production quota over replacement costs $(\$)$ and farms' management practices and animal welfare indicators on 126 freestall farms in Alberta, Ontario, and Québec, Canada

\begin{tabular}{lrrr}
\hline Model/predictor & $\beta$ & \multicolumn{1}{c}{$95 \%$ CI } & $P$-value \\
\hline Milk production genetic index & 0.27 & $0.055,0.478$ & 0.014 \\
Cows with neck lesion, ${ }^{\%}$ & 5.07 & $1.097,9.040$ & 0.013 \\
Cows with neck lesion $\times$ milk genetic index & -0.01 & $-0.019,-0.000$ & 0.048 \\
\hline
\end{tabular}

${ }^{1}$ Estimated using the 40 cows per herd. 
producers should aim to keep lameness and leg lesions prevalence to a minimum to maximize their cows' productivity and longevity and their farm profitability. Similarly, these results highlight the importance of good stall management in terms of dryness and cleanliness for increased milk production and quality.

\section{ACKNOWLEDGMENTS}

This research was supported primarily by Agriculture and Agri-Food Canada, and by additional contributions from Dairy Farmers of Canada, the Canadian Dairy Network, and the Canadian Dairy Commission under the Agri-Science Clusters Initiative. As per the research agreement, aside from providing financial support, the funders had no role in the design and conduct of the studies, data collection and analysis, or interpretation of the data. Researchers maintain independence in conducting their studies, own their data, and report the outcomes regardless of the results. The decision to publish the findings rests solely with the researchers. This research was also funded by the Fonds Québécois de la Recherche sur la Nature et les Technologies (FQRNT; Québec City, Québec, Canada)-Novalait (Quebec, Quebec, Canada)-Ministère de l'Agriculture, des Pêcheries et de l'Alimentation du Québec (MAPAQ; Québec, Québec, Canada), and by the Alberta Livestock and Meat Agency and Alberta Milk (Edmonton, Alberta, Canada). The authors also thank the graduate students and postdoctoral fellows who organized and collected the data: Jenny Gibbons and Gemma Charlton (Agriculture and Agri-Food Canada, Agassiz, British Columbia, Canada), Clémence Nash and Jessica Zaffino (University of Guelph, Guelph, Ontario, Canada), Véronique Bouffard and François Bécotte (Laval University, Québec City, Québec, Canada), and Laura Solano and Guilherme Bond (University of Calgary, Calgary, Alberta, Canada).

\section{REFERENCES}

AAFC (Agriculture and Agri-Food Canada). 2016. Statistics of the Canadian Dairy Information Center. Accessed Nov. 16, 2016. http: //dairyinfo.gc.ca/index_f.php?s1=dff-fcil\&menupos=1.1.

Anderson, N. 2016. Dairy cow comfort-Free-stall dimensions. Accessed Mar. 20, 2017. http://www.omafra.gov.on.ca/english/livestock/ dairy/facts/freestaldim.htm.

Bennett, R., A. Kehlbacher, and K. Balcombe. 2012. A method for the economic valuation of animal welfare benefits using a single welfare score. Anim. Welf. 21:125-130. https://doi.org/10.7120/ $096272812 X 13345905674006$.

Bernardi, F., J. Fregonesi, C. Winckler, D. M. Veira, M. A. G. von Keyserlingk, and D. M. Weary. 2009. The stall-design paradox: Neck rails increase lameness but improve udder and stall hygiene. J. Dairy Sci. 92:3074-3080. https://doi.org/10.3168/jds.2008-1166.

Blackie, N., J. Amory, E. Bleach, and J. Scaife. 2011. The effect of lameness on lying behaviour of zero grazed Holstein dairy cattle.
Appl. Anim. Behav. Sci. 134:85-91. https://doi.org/10.1016/j .applanim.2011.08.004.

Bouffard, V., A. M. de Passillé, J. Rushen, E. Vasseur, C. G. R. Nash, D. B. Haley, and D. Pellerin. 2017. Effect of following recommendations for tiestall configuration on neck and leg lesions, lameness, cleanliness, and lying time in dairy cows. J. Dairy Sci. 100:29352943. https://doi.org/10.3168/jds.2016-11842.

Charlton, G. L., D. B. Haley, J. Rushen, and A. M. de Passillé. 2014. Stocking density, milking duration, and lying times of lactating cows on Canadian freestall dairy farms. J. Dairy Sci. 97:26942700. https://doi.org/10.3168/jds.2013-6923.

Christensen, T., A. Lawrence, M. Lund, A. Stott, and P. Sandoe. 2012. How can economists help to improve animal welfare? Anim. Welf. 21:1-10. https://doi.org/10.7120/096272812X13345905673449.

de Graaf, S., E. J. Van Loo, J. Bijttebier, F. Vanhonacker, L. Lauwers, F. A. M. Tuyttens, and W. Verbeke. 2016. Determinants of consumer intention to purchase animal-friendly milk. J. Dairy Sci. 99:8304-8313. https://doi.org/10.3168/jds.2016-10886.

Deming, J. A., R. Bergeron, K. E. Leslie, and T. J. DeVries. 2013. Associations of housing, management, milking activity, and standing and lying behavior of dairy cows milked in automatic systems. J. Dairy Sci. 96:344-351. https://doi.org/10.3168/jds.2012-5985.

Dohmen, W., F. Neijenhuis, and H. Hogeveen. 2010. Relationship between udder health and hygiene on farms with an automatic milking system. J. Dairy Sci. 93:4019-4033. https://doi.org/10.3168/ jds.2009-3028.

Fregonesi, J. A., D. M. Veira, M. A. G. von Keyserlingk, and D. M. Weary. 2007. Effects of bedding quality on lying behavior of dairy cows. J. Dairy Sci. 90:5468-5472. https://doi.org/10.3168/jds.2007 -0494 .

Gibbons, J., E. Vasseur, J. Rushen, and A. M. de Passillé. 2012. A training programme to ensure high repeatability of injury scoring of dairy cows. Anim. Welf. 21:379-388. https://doi.org/10.7120/ 09627286.21.3.379.

Grant, R. 2007. Taking advantage of natural behavior improves dairy cow performance. Pages 225-236 in Western Dairy Management Conf. Proc., Reno, NV.

Green, L. E., V. J. Hedges, Y. H. Schukken, R. W. Blowey, and A. J. Packington. 2002. The impact of clinical lameness on the milk yield of dairy cows. J. Dairy Sci. 85:2250-2256. https://doi.org/10 .3168/jds.S0022-0302(02)74304-X.

Hansson, H., and C. J. Lagerkvist. 2016. Dairy farmers' use and nonuse values in animal welfare: Determining the empirical content and structure with anchored best-worst scaling. J. Dairy Sci. 99:579-592. https://doi.org/10.3168/jds.2015-9755.

Higginson Cutler, J. H., J. Rushen, A. M. de Passillé, J. Gibbons, K. Orsel, E. Pajor, H. W. Barkema, L. Solano, D. Pellerin, D. Haley, and E. Vasseur. 2017. Producer estimates of prevalence and perceived importance of lameness in dairy herds with tiestalls, freestalls and automated milking systems. J. Dairy Sci. 100:98719880. https://doi.org/10.3168/jds.2017-13008.

Ito, K., M. A. G. von Keyserlingk, S. J. LeBlanc, and D. M. Weary. 2010. Lying behavior as an indicator of lameness in dairy cows. J. Dairy Sci. 93:3553-3560. https://doi.org/10.3168/jds.2009-2951.

Ito, K., D. M. Weary, and M. A. G. von Keyserlingk. 2009. Lying behavior: Assessing within- and between-herd variation in free-stall housed dairy cows. J. Dairy Sci. 92:4412-4420. https://doi.org/10 $.3168 /$ jds.2009-2235.

Kauppinen, T., A. Valros, and K. Mikko Vesala. 2013. Attitudes of dairy farmers toward cow welfare in relation to housing, management and productivity. Anthrozoos 26:405-420. https://doi.org/10 $.2752 / 175303713 X 13697429463718$.

Kielland, C., K. E. Bøe, A. J. Zanella, and O. Østerås. 2010. Risk factors for skin lesions on the necks of Norwegian dairy cows. J. Dairy Sci. 93:3979-3989. https://doi.org/10.3168/jds.2009-2909.

Ledgerwood, D. N., C. Winckler, and C. B. Tucker. 2010. Evaluation of data loggers, sampling intervals, and editing techniques for measuring the lying behavior of dairy cattle. J. Dairy Sci. 93:51295139. https://doi.org/10.3168/jds.2009-2945.

Lombard, J. E., C. B. Tucker, M. A. G. von Keyserlingk, C. A. Kopral, and D. M. Weary. 2010. Associations between cow hygiene, 
hock injuries, and free stall usage on US dairy farms. J. Dairy Sci. 93:4668-4676. https://doi.org/10.3168/jds.2010-3225.

McInerney, J. 1998. Animal welfare: Ethics, economics and productivity. Cattle Pract. 6:89-90.

Nash, C., D. Kelton, E. Vasseur, T. DeVries, D. Parent, D. Pellerin, K. Carrier, E. Pajor, J. Rushen, A. M. de Passillé, J. Coe, and D. B. Haley. 2018. A survey of practices implemented to improve cow comfort following an initial assessment on Canadian dairy farms. Can. J. Anim. Sci. https://doi.org/10.1139/cjas-2015-0012.

National Milk Producers Federation. 2016. National dairy FARM (Farmers Assuring Responsible Management) program 2017 animal care reference manual. Accessed Dec. 12, 2016. http://www .nationaldairyfarm.com/.

Norring, M., E. Manninen, A. M. de Passillé, J. Rushen, L. Munksgaard, and H. Saloniemi. 2008. Effects of sand and straw bedding on the lying behavior, cleanliness, and hoof and hock injuries of dairy cows. J. Dairy Sci. 91:570-576. https://doi.org/10.3168/jds 2007-0452.

PLQ. 2016. L'évolution de la production laitière Québécoise 2015. In Le Producteur de Lait québécois. Longueuil, Québec, Canada. June 2016:38.

Sant'anna, A. C., and M. J. R. Paranhos da Costa. 2011. The relationship between dairy cow hygiene and somatic cell count in milk. J. Dairy Sci. 94:3835-3844. https://doi.org/10.3168/jds.2010-3951.

Solano, L., H. W. Barkema, E. A. Pajor, S. Mason, S. J. LeBlanc, C. G. R. Nash, D. B. Haley, D. Pellerin, J. Rushen, A. M. de Passillé, E. Vasseur, and K. Orsel. 2016. Associations between lying behavior and lameness in Canadian Holstein-Friesian cows housed in freestall barns. J. Dairy Sci. 99:2086-2101. https://doi.org/10 $.3168 /$ jds.2015-10336.

Solano, L., H. W. Barkema, E. A. Pajor, S. Mason, S. J. LeBlanc, J. C. Zaffino Heyerhoff, C. G. R. Nash, D. B. Haley, E. Vasseur, D. Pellerin, J. Rushen, A. M. de Passillé, and K. Orsel. 2015. Prevalence of lameness and associated risk factors in Canadian HolsteinFriesian cows housed in freestall barns. J. Dairy Sci. 98:6978-6991. https://doi.org/10.3168/jds.2015-9652.

van Gastelen, S., B. Westerlaan, D. J. Houwers, and F. J. C. M. van Eerdenburg. 2011. A study on cow comfort and risk for lameness and mastitis in relation to different types of bedding materials. J. Dairy Sci. 94:4878-4888. https://doi.org/10.3168/jds.2010-4019.

Vasseur, E., J. Gibbons, J. Rushen, and A. M. de Passillé. 2013. Development and implementation of a training program to ensure high repeatability of body condition scoring of dairy cows. J. Dairy Sci. 96:4725-4737. https://doi.org/10.3168/jds.2012-6359.

Vasseur, E., J. Gibbons, J. Rushen, D. Pellerin, E. Pajor, D. Lefebvre, and A. M. de Passillé. 2015. An assessment tool to help produc- ers improve cow comfort on their farms. J. Dairy Sci. 98:698-708. https://doi.org/10.3168/jds.2014-8224.

Vasseur, E., J. Rushen, D. B. Haley, and A. M. de Passillé. 2012. Sampling cows to assess lying time for on-farm animal welfare assessment. J. Dairy Sci. 95:4968-4977. https://doi.org/10.3168/ jds.2011-5176

Ventura, B. A., M. A. G. von Keyserlingk, and D. M. Weary. 2015. Animal welfare concerns and values of stakeholders within the dairy industry. J. Agric. Environ. Ethics 28:109-126.

Villettaz Robichaud, M., J. Rushen, A. M. de Passillé, E. Vasseur, D. B. Haley, and D. Pellerin. 2018. Is the profitability of Canadian freestall farms associated with their performance on an animal welfare assessment? J. Dairy Sci. 101:2350-2358. https://doi.org/ $10.3168 /$ jds.2017-13315.

von Keyserlingk, M. A. G., A. Barrientos, K. Ito, E. Galo, and D. M. Weary. 2012. Benchmarking cow comfort on North American freestall dairies: Lameness, leg injuries, lying time, facility design, and management for high-producing Holstein dairy cows. J. Dairy Sci. 95:7399-7408. https://doi.org/10.3168/jds.2012-5807.

Webster, J. 2012. Critical control points in the delivery of improved animal welfare. Anim. Welf. 21:117-123. https://doi.org/10.7120/ $096272812 X 13345905673962$.

Wechsler, B., J. Schaub, K. Friedli, and R. Hauser. 2000. Behaviour and leg injuries in dairy cows kept in cubicle systems with straw bedding or soft lying mats. Appl. Anim. Behav. Sci. 69:189-197. https://doi.org/10.1016/S0168-1591(00)00134-9.

Westin, R., A. Vaughan, A. M. de Passillé, T. J. DeVries, E. A. Pajor, D. Pellerin, J. M. Siegford, E. Vasseur, and J. Rushen. 2016. Lying times of lactating cows on dairy farms with automatic milking systems and the relation to lameness, leg lesions, and body condition score. J. Dairy Sci. 99:551-561. https://doi.org/10.3168/jds .2015-9737.

Wolf, C., G. T. Tonsor, M. G. S. McKendree, D. U. Thomson, and J. C. Swanson. 2015. U.S. Dairy Farmer Welfare Perceptions and Attitudes: Survey Summary. MSU AFRE Staff Paper 2015-04. Michigan State University, East Lansing.

Wolf, C., G. T. Tonsor, M. G. S. McKendree, D. U. Thomson, and J. C. Swanson. 2016. Public and farmer perceptions of dairy cattle welfare in the United States. J. Dairy Sci. 99:5892-5903. https:// doi.org/10.3168/jds.2015-10619.

Zaffino Heyerhoff, J. C., S. J. LeBlanc, T. J. DeVries, C. G. R. Nash, J. Gibbons, K. Orsel, H. W. Barkema, L. Solano, J. Rushen, A. M. de Passillé, and D. B. Haley. 2014. Prevalence of and factors associated with hock, knee, and neck injuries on dairy cows in freestall housing in Canada. J. Dairy Sci. 97:173-184. https://doi .org/10.3168/jds.2012-6367. 